\title{
SUPERVISI AKADEMIK MENINGKATKAN KOMPETENSI PEDAGOGIK GURU
}

\author{
Heri Mujiono \\ SDN Kepanjen 2 Jombang \\ email: herjio70@gmail.com
}

\begin{abstract}
The condition of the teacher at SDN Kepanjen 2 shows far from ideal conditions. The results of preliminary surveys conducted by researchers in the execution of teachers ' duties, seven aspects of pedagogic competence teachers have not seen showing the skills of teachers in carrying out learning. Academic supervision is a selected action researcher to help teachers develop pedagogic skills of the teacher. This research is done cycle by cycle according to the concept of research action, planned there are 2 cycles with each cycle implemented measures planning, implementation, observation, reflection. Data collection techniques used in research using observations, interviews and documentation studies. The results of data analysis obtained exposure that proves that of the seven competencies that are targeted to research obtained an average value increase of $86 \%$. So it can be concluded that the application of academic supervision can improve the pedagogic competence of teachers.
\end{abstract}

Keywords: Supervision, Academic, Pedagogic Competence

\begin{abstract}
Abstrak: Kondisi guru di SDN Kepanjen 2 menunjukkan masih jauh dari kondisi ideal. Hasil survei awal yang dilakukan peneliti dalam pelaksanaan tugas guru, tujuh aspek kompetensi pedagogik guru belum tampak menunjukkan keterampilan guru dalam melaksanakan pembelajaran. Supervisi akademik adalah tindakan yang dipilih peneliti untuk membantu guru mengembangkan kemampuan pedagogik guru. Penelitian ini dilakukan siklus demi siklus sesuai dengan konsep penelitian tindakan, direncanakan ada 2 siklus dengan masing masing siklus dilaksanakan langkah-langkah Perencanaan (planning), Pelaksanaan (Acting), Pengamatan (Observating). Refleksi (Reflecting). Teknik pengumpulan data yang digunakan dalam penelitian menggunakan observasi, wawancara dan studi dokumentasi. Hasil analisa data diperoleh paparan yang membuktikan bahwa dari tujuh kompetensi yang menjadi sasaran penelitian diperoleh nilai rata-rata peningkatan $86 \%$. Jadi dapat disimpulkan bahwa penerapan supervisi akademik dapat meningkatkan kompetensi pedagogik guru.
\end{abstract}

Kata kunci: Supervisi, Akademik, Kompetensi Pedagogik

Esensi sebuah pendidikan persekolahan adalah proses pembelajaran. Tidak ada kualitas pendidikan persekolahan tanpa kualitas pembelajaran (Nurgiyantoro, 2004). Berbagai upaya peningkatan mutu pendidikan persekolahan dapat dianggap kurang berguna bilamana belum menyentuh perbaikan proses pembe lajaran. Oleh karena itu dalam rangka peningkatan kualitas pendidikan persekolahan Pemerintah, dalam hal ini Departemen Pendidikan Nasional, mengembangkan berbagai program yang diharapkan dapat meningkatkan kualitas pembelajaran.

Mutu pembelajaran sangat ditentukan oleh kualitas dan kompetensi guru. fokus pada kompetensi pedagogik, guru dituntut untuk dapat melaksanakan pembelajaran dengan memperhatikan perencanaannya, perhatian pada karakteristik peserta didiknya, pemahaman peserta didik dari segi kompetensi dan tingkat pemahaman terkait materi yang dipelajari, termasuk memberikan perhatian pengembangan potensi dan memberikan penilaian serta evaluasi tingkat capaian kompetensi peserta didik (Astuti, 2016).

Secara rinci dalam Permenegpan dan RB 16/2009 tentang Jabatan Fungsional Guru dan Angka Kreditnya, kompetensi pedagogik guru meliputi; menguasai karakteristik peserta didik, menuasai teori belajar dan prinsip-prinsip pembelajaran yang mendidik, pengembangan kurikulum, kegiatan pembelajaran yang mendidik, pengembangan potensi peserta didik, 
komunikasi dengan peserta didik, penilaian dan evaluasi (Wardani, 2013).

Kondisi riil yang dimiliki oleh sebagian guru di SDN Kepanjen 2 menunjukkan kondisi yang masih jauh dari kondisi ideal. Hasil survei awal yang dilakukan peneliti dalam pelaksanaan tugas guru, tujuh aspek kompetensi pedagogik guru belum tampak menunjukkan keterampilan guru dalam melaksanakan pembelajaran. Sehubungan dengan kondisi riil tersebut peneliti memandang tepat jika guru perlu diberikan tindakan untuk meningkatkan mutu pembelajaran yang secara umum akan meningkatkan pelayanan akademik yang bermutu.

Supervisi akademik adalah tindakan membantu guru mengembangkan kemampuannya mencapai tujuan pembelajaran yang direncanakan untuk peserta didiknya (Dharma, 2007). Melalui supervisi akademik diharapkan kualitas akademik yang dilakukan guru semakin meningkat. Menurut Sergiovanni (dalam (Pidarta, 2011) ada tiga tujuan supervisi akademik yaitu pengembangan profesional, pengawasan kualitas, dan penumbuhan motivasi.

Tindakan tepat untuk meningkatkan mutu kompetensi pedagogik guru berdasar kajian peneliti adalah tindakan supervisi akademik yang secara konseptual membantu guru dalam meningkatkan mutu pembelajaran. Perilaku supervisi akademik secara langsung berhubungan dan berpengaruh terhadap perilaku guru. Ini berarti, melalui supervisi akademik, supervisor mempengaruhi perilaku mengajar guru sehingga perilakunya semakin baik dalam mengelola proses pembelajaran. Selanjutnya perilaku mengajar guru yang baik itu akan mempengaruhi perilaku belajar peserta didik. Dengan demikian, diduga peneliti bahwa penerapan supervisi akademik dapat meningkatkan kompetensi pedagogik guru tujuan akhir supervisi akademik adalah terbinanya perilaku belajar peserta didik yang lebih baik. Oleh karena itu penelitian ini melaksanakan tindakan supervisi akademik untuk meningkatkan kompetensi pedagogik guru di SDN Kepanjen 2 Jombang.

\section{METODE}

Penelitian ini menggunakan pendekatan kualitatif dengan jenis penelitian tindakan. Penelitian tindakan adalah suatu intervensi dalam skala kecil terhadap kegiatan yang telah berjalan dengan dibarengi refleksi terhadap hasilnya (Arikunto, 2005). Berdasarkan tujuan penelitian yang telah ditetapkan, maka jenis penelitian ini adalah survei eksplanatoris (Riyanto, 2007). Lokasi penelitian tindakan kelas ini dilakukan di SDN Kepanjen 2 Jombang, dengan subyek penelitian 14 guru yang terdiri dari 8 Guru kelas dan 6 guru mata pelajaran.

Penelitian tindakan sekolah tentang penerapan supervisi akademik Teknis Klinis untuk meningkatkan kompetensi pedagogik di SDN Kepanjen 2 Jombang ini, peneliti membuat target keberhasilan rata-rata setiap aspek kompetensi pedagogik minimal $75 \%$ atau dalam konversi nilai 3, dengan dasar bahwa perilaku guru dalam pembelajaran merupakan agenda program utama dari sekian program penyelenggaraan pendidikan di SDN Kepanjen 2 dan pembelajaran merupakan inti dari kualitas pendidikan yang ditegaskan dalam fungsi sekolah sebagai lembaga pendidikan. Adapun maksud dari setiap aspek kompetensi pedagogik $75 \%$ adalah sebagai berikut: 1) Pencapaian kompetensi menguasai karakteristik peserta didik $75 \%$; 2) Pencapaian kompetensi menguasai teori belajar dan prinsip-prinsip pembelajaran yang mendidik $75 \%$; 3) Pencapaian kompetensi pengembangan kurikulum $75 \%$; 4) Pencapaian kompetensi kegiatan pembelajaran yang mendidik $75 \%$; 5) Pencapaian kompetensi pengembang-an potensi peserta didik 75\%; 6) Pencapaian kompetensi komunikasi dengan Peserta didik 75\%; 7) Pencapaian kompetensi penilaian \& evaluasi $75 \%$.

Penelitian ini dilakukan siklus demi siklus sesuai dengan konsep penelitian tindakan, direncanakan ada 2 siklus dengan masing masing siklus dilaksanakan langkahlangkah Perencanaan (planning), Pelaksanaan (Actuating), Pengamatan (Observating). Refleksi (Reflecting). Teknik pengumpulan data yang digunakan dalam penelitian, sesuai dengan desain penelitian yaitu menggunakan observasi, wawancara dan studi dokumentasi (Widoyoko, 2012). 
Observasi digunakan untuk memperoleh data dan fakta tentang Kemampuan dan keterampilan guru dalam penyusunan pembelajaran dan pelaksanaan pembelajaran. Wawancara untuk memperoleh data tentang pendapat guru terhadap adanya inovasi pembelajaran yang dikaitkan dengan penelitian tindakan, perbaikan konsep perencanan pembelajar-an sampai dengan instrumen penilaiannya, dan hasil kegiatan pembelajaran yang telah dilakukan. Studi dokumentasi yang dimaksudkan adalah menganlisis dokumen yang dijadikan sumber data pada penelitian meliputi: (1) program tertulis rencana pembelajaran yang dirumuskan guru (2) dokumen pelaksanaan pembelajaran yang berkaitan dengan pelaksanaan pembelajaran guru termasuk catatan untuk program tindak lanjut pembelajaran.

Teknik analisis data dalam penelitian ini menggunakan perpaduan antara teknik analisis data kualitatif dan teknik analisis data kualitatif karena sebagian data yang diperoleh berupa data kuantitatif. Analisis data kualitatif dari penelitian ini akan dilakukan melalui 3 tahap, yaitu reduksi data, paparan data, dan penyimpulan. Sedangkan analisis data kuantitatif menggunakan analisis data jenis statistik deskriptif karena adanya data-data kemampuan guru dari hasil pengamatan dan dihitung nilai mean dengan rumus

$$
\sum M=\frac{f}{N} x 100 .
$$

Kriteria atau ukuran yang digunakan ialah menentukan nilai (persentase) yang diklasifikasikan atas dasar tingkatan sebagai berikut:

\begin{tabular}{cc}
\hline $\begin{array}{c}\text { Nilai } \\
\text { Kompetensi }\end{array}$ & Rentang Total Skor "X" \\
\hline 1 & $0 \%<X \leq 25 \%$ \\
2 & $25 \%<X \leq 50 \%$ \\
3 & $50 \%<X \leq 75 \%$ \\
4 & $75 \%<X \leq 100 \%$ \\
\hline
\end{tabular}

\section{HASIL DAN PEMBAHASAN}

Berdasarkan hasil observasi yang dilakukan peneliti selama melaksanakan penelitian yang terdiri dari 2 siklus, peneliti dapat sampaikan rangkuman hasil setiap siklus sebagai berikut:

\section{Aspek Kompetensi menguasai karakteristik peserta didik.}

Kompetensi penguasaan terhadap karakteristik peserta didik dalam dua siklus menunjukkan perubahan pada butir-butir tertentu. Indikotor yang tidak tampak ada perubahan dari 24 orang guru, ditemukan pada kemampuan identifikasi penyebab penyimpangan perilaku peserta didik, dan kemampuan pengembangan dan pengatasi kekurangan peserta didik. Perubahan tampak pada kemampuan identifikasi karakter dan pengelolaan kelas dalam memberikan kesempatan belajar peserta didik. Berikut tabel 1 menyajikan rekap dua siklus nilai kompetensi dalam penguasai karakteristik peserta didik.

Tabel 1. Rekap dua siklus Nilai Kompetensi dalam menguasai karakteristik peserta didik

\begin{tabular}{|c|c|c|c|}
\hline No & Indikator Kompetensi & $\begin{array}{c}\text { Siklus } \\
1\end{array}$ & $\begin{array}{c}\text { Siklus } \\
2\end{array}$ \\
\hline 1 & $\begin{array}{l}\text { Guru dapat mengidentifi- } \\
\text { kasi karakteristik belajar } \\
\text { setiap peserta didik }\end{array}$ & $50 \%$ & $100 \%$ \\
\hline 2 & $\begin{array}{c}\text { Guru memastikan peserta } \\
\text { didik berkesempatan } \\
\text { berpartisipasi aktif }\end{array}$ & $57 \%$ & $71 \%$ \\
\hline 3 & $\begin{array}{c}\text { Guru dapat mengatur } \\
\text { kelas peserta didik } \\
\text { dengan kelainan fisik dan } \\
\text { kemam-puan belajar yang } \\
\text { berbeda }\end{array}$ & $75 \%$ & $100 \%$ \\
\hline 4 & $\begin{array}{c}\text { Guru mencoba } \\
\text { mengetahui penyebab } \\
\text { penyimpangan perilaku } \\
\text { peserta didik }\end{array}$ & $50 \%$ & $50 \%$ \\
\hline 5 & $\begin{array}{c}\text { Guru membantu mengem } \\
\text { bangkan potensi dan } \\
\text { mengatasi kekurangan } \\
\text { peserta didik }\end{array}$ & $50 \%$ & $50 \%$ \\
\hline 6 & $\begin{array}{l}\text { Guru memperhatikan } \\
\text { peserta didik dengan } \\
\text { kelemahan fisik sehingga } \\
\text { tidak termarginalkan }\end{array}$ & $100 \%$ & $100 \%$ \\
\hline
\end{tabular}

Aspek Kompetensi Menguasai Teori Belajar Dan Prinsip-Prinsip Pembelajaran Yang Mendidik

Kompetensi penguasaan teori belajar dan prinsip-prinsip pembelajaran yang mendidik merupakan modal bagi guru untuk dapat mengatur proses pembelajaran yang meliputi pengemnagan ranah olah pikir, emosi dan keterampilan peserta didik. Tabel 2 adalah rekap dua siklus nilai kompetensi teori belajar dan prinsip-prinsip pembelajaran yang mendidik. 
Tabel 2. Rekap dua siklus Nilai Kompetensi menguasai teori belajar dan prinsip-prinsip pembelajaran yang mendidik

\begin{tabular}{|c|c|c|c|}
\hline No & Indikator Kompetensi & $\begin{array}{c}\text { Siklus } \\
1\end{array}$ & $\begin{array}{c}\text { Siklus } \\
2\end{array}$ \\
\hline 1 & $\begin{array}{c}\text { Guru memberi } \\
\text { kesempatan kepada } \\
\text { peserta didik untuk } \\
\text { menguasai materi. }\end{array}$ & $100 \%$ & $100 \%$ \\
\hline 2 & $\begin{array}{c}\text { Guru selalu memastikan } \\
\text { tingkat pemahaman } \\
\text { peserta didik terhadap } \\
\text { materi }\end{array}$ & $50 \%$ & $50 \%$ \\
\hline 3 & $\begin{array}{c}\text { Guru dapat } \\
\text { menjelaskan alasan } \\
\text { pelaksanaan } \\
\text { kegiatan/aktivitas yang } \\
\text { dilakukannya }\end{array}$ & $50 \%$ & $61 \%$ \\
\hline 4 & $\begin{array}{c}\text { Guru menggunakan } \\
\text { berbagai teknik untuk } \\
\text { memotiviasi kemauan } \\
\text { belajar }\end{array}$ & $50 \%$ & $79 \%$ \\
\hline 5 & $\begin{array}{c}\text { Guru merencanakan } \\
\text { kegiatan pembelajaran } \\
\text { yang saling terkait satu } \\
\text { sama lain }\end{array}$ & $68 \%$ & $79 \%$ \\
\hline 6 & $\begin{array}{c}\text { Guru memperhatikan } \\
\text { respon peserta didik } \\
\text { yang belum/kurang } \\
\text { memahami materi }\end{array}$ & $50 \%$ & $100 \%$ \\
\hline
\end{tabular}

Perkembangan

perubahan

kompetensi pedagogik menunjukkan peningkatan akibat tindakan pada siklus kedua. Perubahan yang terjadi antara lain guru menggunakan berbagai teknik untuk memotivasi kemauan belajar peserta didik. Guru sudah memperhatikan/merespon peserta didik yang kurang memahami materi pembelajaran. Namun di sana masih ada butir indikator yang masih belum mengalami peningkatan yaitu tindakan guru untuk memastikan tingkat pemahaman peserta didik tentang apa yang dipelajarai.

\section{Aspek Kompetensi Pengembangan Kurikulum Kompetetansi}

Pengembangan kurikulum kemampuan yang penting dalam pelaksanaan tugas guru sebagai pendidik. Kurikulum merupakan tata nilai yang tersusun secara sistematik perlu diuraikan bagaiman proses pencapaian atau menginternalisasikan pada pengalaman peserta didik. Merancang pembelajaran memerlukan keahlian mengorganisasian materi untuk disampaikan kepada peserta didik. Beberapa hal yang menjadi pertimbangan penting dalam merancang pembelajaran adalah usia perkembangan peserta didik, pengorganisasian materi atau keluasan materi, tingkat kemampuan peserta didik dan ruang pembelajaran. Berikut tabel 3 tentang rekap penilaian perbaikan kompetensi pengembangan kurikulum yang dibandingkan dalam dua siklus.

Tabel 3. Rekap Dua Siklus Nilai Kompetensi pengembangan Kurikulum

\begin{tabular}{cccc}
\hline No & Indikator Kompetensi & $\begin{array}{c}\text { Siklus } \\
\mathbf{1}\end{array}$ & $\begin{array}{c}\text { Siklus } \\
\mathbf{2}\end{array}$ \\
\hline $1 \quad \begin{array}{c}\text { Guru dapat menyusun } \\
\text { silabus yang sesuai } \\
\text { dengan kurikulum } \\
\text { Guru merancang } \\
\text { rencana pembelajaran } \\
\text { yang sesuai dengan } \\
\text { silabus }\end{array}$ & $50 \%$ & $50 \%$ \\
$3 \quad \begin{array}{c}\text { Guru mengikuti urutan } \\
\text { materi memperhatikan } \\
\text { tujuan pembelajaran. } \\
\text { Guru memilih materi } \\
\text { sesuai tujuan, mutakhir, } \\
\text { usia dan tingkat } \\
\text { kemampuan belajar } \\
\text { peserta didik, dan } \\
\text { konteks kehidupan } \\
\text { sehari-hari }\end{array}$ & $71 \%$ & $71 \%$ \\
4 & $100 \%$ & \\
\hline
\end{tabular}

Pada tabel tersebut tampak bahwa dampak dari tindakan supervisi akademik dapat membantu guru dalam memberdayakan kemampuannya untuk melaksanakan pembelajaran pada peserta didik. Perkembangan kemampuan ini diawali dari peningkatan kemampuan guru mengurutkan materi dengan pengorganisasian yang tepat sesuai dengan pemetaan tujuan pembelajaran.

\section{Aspek Kompetensi kegiatan pembelajaran yang mendidik}

Kompetensi kegiatan pembelajaran yang mendidik merupakan kemampuan guru yang sangat penting dalam merujuk sebagai kegiatan tugas pokok guru. Peningkatan kompetensi ini dapat disimak dalam tabel berikut:

Tabel 4. Rekap dua siklus Nilai Kompetensi kegiatan pembelajaran yang mendidik

\begin{tabular}{cccc}
\hline No & Indikator Kompetensi & $\begin{array}{c}\text { Siklus } \\
\mathbf{1}\end{array}$ & $\begin{array}{c}\text { Siklus } \\
\mathbf{2}\end{array}$ \\
\hline 1 & Guru membelajarkan sesuai & $50 \%$ & $100 \%$ \\
rancangan & Guru membantu proses & $71 \%$ & $71 \%$ \\
2 & belajar peserta didik, & $50 \%$ & $93 \%$ \\
3 & Guru mengkomunikasi-kan & 50 &
\end{tabular}




\begin{tabular}{|c|c|c|c|}
\hline No & Indikator Kompetensi & $\begin{array}{c}\text { Siklus } \\
1\end{array}$ & $\begin{array}{l}\text { Siklus } \\
2\end{array}$ \\
\hline 4 & $\begin{array}{c}\text { informasi baru } \\
\text { Guru menyikapi kesalahan } \\
\text { peserta didik }\end{array}$ & $50 \%$ & $50 \%$ \\
\hline 5 & $\begin{array}{c}\text { Guru melaksanakan } \\
\text { pembelajaran sesuai isi } \\
\text { kurikulum }\end{array}$ & $50 \%$ & $50 \%$ \\
\hline 6 & $\begin{array}{l}\text { Guru melakukan pembela- } \\
\text { jaran secara bervariasi }\end{array}$ & $50 \%$ & $50 \%$ \\
\hline 7 & $\begin{array}{c}\text { Guru mengelola kelas } \\
\text { dengan efektif }\end{array}$ & $50 \%$ & $50 \%$ \\
\hline 8 & $\begin{array}{l}\text { Guru mampu menyesuai- } \\
\text { kan aktivitas pembelajaran } \\
\text { dengan kondisi kelas. }\end{array}$ & $71 \%$ & $82 \%$ \\
\hline 9 & $\begin{array}{l}\text { Guru memberikan } \\
\text { kesempatan peserta didik }\end{array}$ & $100 \%$ & $100 \%$ \\
\hline 10 & $\begin{array}{l}\text { Guru mengatur pembela- } \\
\text { jaran secara sistematis }\end{array}$ & $50 \%$ & $50 \%$ \\
\hline 11 & $\begin{array}{l}\text { Guru menggunakan alat } \\
\text { bantu, dan/atau audiovi- } \\
\text { sual (termasuk TIK) }\end{array}$ & $50 \%$ & $79 \%$ \\
\hline
\end{tabular}

Memperhatikan tabel tersebut dapat dibandingkan perkembangan peningkatan kompetensi pada masing-masing butir-butir indikator kompetensi dalam dua siklus. Indikator yang meningkat adalah aktivitas pembelajaran guru sesuai dengan rencana, guru mengkomunikasikan informasi baru, perancangan kegiatan disesuaian dengan kondisi kelas, dan penggunaan alat bantu pembalajaran.

\section{Aspek Kompetensi Pengembangan Potensi Peserta Didik}

Aspek kompetensi pengembangan potensi peserta didik memiliki peran penting dalam membantu peserta didik untuk dapat berkembang secara optimal sesuai dengan bakat dan talenta peserta didik. Kecakapan pola belajar, kreativitas berpikir peserta didik dapat berkembangan dengan perlakukan guru yang memberikan pendidikan intensih kepada peserta didik. Tabel berikut memberi-kan gambaran penilaian komptensi guru.

\section{Tabel 5. Rekap Dua Siklus Nilai Kompetensi Pengembangan Potensi Peserta Didik}

\begin{tabular}{|c|c|c|c|}
\hline No. & Indikator Kompetensi & $\begin{array}{c}\text { Siklus } \\
1\end{array}$ & $\begin{array}{l}\text { Siklus } \\
2\end{array}$ \\
\hline 1 & $\begin{array}{l}\text { Guru menganalisis hasil } \\
\text { belajar peserta didik }\end{array}$ & $100 \%$ & $100 \%$ \\
\hline 2 & $\begin{array}{c}\text { Guru mendorong peserta } \\
\text { didik untuk belajar } \\
\text { Guru memunculkan daya }\end{array}$ & $71 \%$ & $71 \%$ \\
\hline 3 & $\begin{array}{l}\text { kreativitas dan berfikir } \\
\text { kritis peserta didik. }\end{array}$ & $50 \%$ & $50 \%$ \\
\hline 4 & Guru membantu dan & $50 \%$ & $100 \%$ \\
\hline
\end{tabular}

\begin{tabular}{|c|c|c|c|}
\hline No. & Indikator Kompetensi & $\underset{1}{\text { Siklus }}$ & $\begin{array}{c}\text { Siklus } \\
2\end{array}$ \\
\hline & $\begin{array}{c}\text { perhatian kepada setiap } \\
\text { individu. }\end{array}$ & & \\
\hline 5 & $\begin{array}{c}\text { Guru mengidentifikasi } \\
\text { bakat, minat, potensi, dan } \\
\text { kesulitan belajar } \\
\text { Guru memberikan }\end{array}$ & $50 \%$ & $79 \%$ \\
\hline 6 & $\begin{array}{l}\text { kesempatan belajar } \\
\text { dengan cara belajarnya } \\
\text { Guru memusatkan }\end{array}$ & $71 \%$ & $71 \%$ \\
\hline 7 & $\begin{array}{l}\text { perhatian pada interaksi } \\
\text { dengan peserta didik }\end{array}$ & $50 \%$ & $75 \%$ \\
\hline
\end{tabular}

Pada tabel tersebut tampak bahwa perubahan perilaku guru setelah mendapatkan tindakan supervisi akademik meliputi butir-butir indikator kemampuan guru dalam mengidentifikasi dengan benar tentang bakat, minat, potensi, dan kesulitan belajar masing-masing peserta didik, dan kemampuan guru memusatkan perhatian pada interaksi dengan peserta didik dan mendorongnya untuk memahami dan menggunakan informasi yang disampaikan. Pada butir indikator yang lain tampat statis belum ada perubahan.

\section{Aspek Kompetensi Komunikasi Dengan Peserta Didik}

Kemampuan guru untuk dapat berkomunikasi dengan peserta didik merupakan relasi personal yang penting dalam kontek dialogis antara pendidi dan peserta didik. Kunci keberhasilan guru dalam upaya membentuk dan mengembangkan potensi sumber daya pendidik adalah sangat ditentukan oleh kemampuan guru dalam mengkomunikasikan materi atau konsep-konsep pengetahuan kepada peserta didik. Pemberdayaan potensi kerja sama peserta didik dalam pelajar sangat ditentukan oleh sejauh mana guru dapat mengkomuni-kasikan ide atau gagasan guru untuk diinternalisasi-kan kepada peserta didik. Hasil penilaian pengaruh tindakan supervisi akademik untuk meningkatkan kompetensi peda-gogik guru dapat dilihat dalam sajian tabel rekap dua siklus nilai kompetensi pengembangan potensi peserta didik berikut.

Tabel 6. Rekap Dua Siklus Nilai Kompetensi Komunikasi dengan Peserta Didik

\begin{tabular}{cccc}
\hline No & Indikator Kompetensi & $\begin{array}{c}\text { Siklus } \\
\mathbf{1}\end{array}$ & $\begin{array}{c}\text { Siklus } \\
\mathbf{2}\end{array}$ \\
\hline 1 & $\begin{array}{c}\text { Guru menggunakan } \\
\text { pertanyaan untuk }\end{array}$ & $100 \%$ & $100 \%$
\end{tabular}




\begin{tabular}{|c|c|c|c|}
\hline No & Indikator Kompetensi & $\underset{1}{\text { Siklus }}$ & $\begin{array}{c}\text { Siklus } \\
2\end{array}$ \\
\hline & $\begin{array}{c}\text { mengetahui } \\
\text { pemahaman dan } \\
\text { menjaga partisipasi }\end{array}$ & & \\
\hline & $\begin{array}{c}\text { peserta didik } \\
\text { Guru memper-hatikan }\end{array}$ & & \\
\hline 2 & $\begin{array}{l}\text { dan men-dengarkan } \\
\text { per-tanyaan dan tang- } \\
\text { gapan peserta didik }\end{array}$ & $50 \%$ & $100 \%$ \\
\hline 3 & $\begin{array}{c}\text { Guru menanggapi } \\
\text { pertanyaan secara } \\
\text { tepat, benar,dan } \\
\text { mutakhir }\end{array}$ & $50 \%$ & $64 \%$ \\
\hline 4 & $\begin{array}{c}\text { Guru menumbuh kan } \\
\text { kerja sama }\end{array}$ & $71 \%$ & $71 \%$ \\
\hline 5 & $\begin{array}{l}\text { Guru mendengar-kan } \\
\text { dan memper hatikan } \\
\text { jawaban peserta didik. }\end{array}$ & $50 \%$ & $50 \%$ \\
\hline 6 & $\begin{array}{l}\text { Guru memberikan } \\
\text { perhatian terhadap } \\
\text { pertanyaan peserta } \\
\text { didik dan merespon }\end{array}$ & $50 \%$ & $71 \%$ \\
\hline
\end{tabular}

Perubahan perilaku guru terkait dengan aspek kompetensi komunikasi dengan peserta didik setelah mendapat-kan perilaku supervisi akademik dalam dua siklus adalah pada butir kemampuan guru dalam memberikan perhatian dan mendengarkan semua pertanyaan dan tanggapan peserta didik, tanpa menginterupsi, kecuali jika diperlukan untuk membantu atau mengklarifikasi pertanyaan/tanggapan tersebut, dan kemampuan guru memberikan perhatian terhadap pertanyaan peserta didik dan meresponnya secara lengkap dan relevan untuk menghilangkan kebingungan pada peserta didik.

\section{Aspek Kompetensi Penilaian Dan Evaluasi}

Kemampuan guru untuk melakukan penilaian dan evaluasi hasil pembelajaran peserta didik. Berikut disajikan rekap dua siklus penilaian kompotensi penilaian dan evaluasi.

Tabel 7. Rekap dua siklus nilai Kompetensi penilaian dan evaluasi

\begin{tabular}{|c|c|c|c|}
\hline No & Indikator Kompetensi & $\begin{array}{c}\text { Siklus } \\
1\end{array}$ & $\underset{2}{\text { Siklus }}$ \\
\hline 1 & $\begin{array}{l}\text { Guru menggunakan } \\
\text { pertanyaan untuk } \\
\text { mengetahui } \\
\text { pemahaman dan } \\
\text { menjaga partisipasi } \\
\text { peserta didik }\end{array}$ & $100 \%$ & $100 \%$ \\
\hline 2 & Guru memper-hatikan & $50 \%$ & $100 \%$ \\
\hline
\end{tabular}

\begin{tabular}{|c|c|c|c|}
\hline No & Indikator Kompetensi & $\begin{array}{c}\text { Siklus } \\
1\end{array}$ & $\begin{array}{l}\text { Siklus } \\
2\end{array}$ \\
\hline & $\begin{array}{l}\text { dan men-dengarkan } \\
\text { per-tanyaan dan tang- } \\
\text { gapan peserta didik }\end{array}$ & & \\
\hline 3 & $\begin{array}{c}\text { Guru menanggapi } \\
\text { pertanyaan secara } \\
\text { tepat, benar,dan } \\
\text { mutakhir }\end{array}$ & $50 \%$ & $64 \%$ \\
\hline 4 & $\begin{array}{c}\text { Guru menumbuh kan } \\
\text { kerja sama }\end{array}$ & $71 \%$ & $71 \%$ \\
\hline 5 & $\begin{array}{l}\text { Guru mendengar-kan } \\
\text { dan memper hatikan } \\
\text { jawaban peserta didik. }\end{array}$ & $50 \%$ & $50 \%$ \\
\hline 6 & $\begin{array}{l}\text { Guru memberikan } \\
\text { perhatian terhadap } \\
\text { pertanyaan peserta } \\
\text { didik dan merespon }\end{array}$ & $50 \%$ & $71 \%$ \\
\hline
\end{tabular}

Pada tabel 7 tampak bahwa dalam perlakukan tindakan supervisi akademik dalam dua siklus, perubahan perilaku guru terkait dengan aspek kompetensi penilaian dan evaluasi. Bahwa yang mengalami banyak peningkatan adalah pada butir indikator penyusunan alat penilaian, dan kemampuan guru dalam memanfaatkan hasil penilaian untuk menyusun rencana perbaikan dan pengayaan.

\section{Rekapitulasi Penilaian Kompetensi Pedagogik Guru Pada Dua Siklus}

Secara keseluruan aspek komptensi pedagogik guru-guru di SDN Kepanjen 2 menunjukkan perubahan setelah disajikan tindakan supervisi akademik. Dari 14 guru prestasi perubahan dari masing-masing aspek dapat dilihat dalam tabel berikut:

Tabel 8. Rekap dua siklus Nilai Kompetensi Pedagogik Guru pada dua siklus

\begin{tabular}{|c|c|c|c|}
\hline No & Aspek Kompetensi & $\begin{array}{c}\text { Siklus } \\
1\end{array}$ & $\begin{array}{c}\text { Siklus } \\
2\end{array}$ \\
\hline & Menguasai & & \\
\hline 1 & $\begin{array}{l}\text { karakteristik peserta } \\
\text { didik }\end{array}$ & $75 \%$ & $86 \%$ \\
\hline 2 & $\begin{array}{l}\text { Menguasai teori belajar } \\
\text { dan prinsip-prinsip } \\
\text { pembelajaran }\end{array}$ & $75 \%$ & $84 \%$ \\
\hline 3 & $\begin{array}{l}\text { Pengembangan } \\
\text { kurikulum }\end{array}$ & $61 \%$ & $86 \%$ \\
\hline 4 & $\begin{array}{l}\text { Kegiatan pembelajaran } \\
\text { yang mendidik }\end{array}$ & $75 \%$ & $84 \%$ \\
\hline 5 & $\begin{array}{l}\text { Pengembangan } \\
\text { potensi peserta didik }\end{array}$ & $75 \%$ & $95 \%$ \\
\hline 6 & $\begin{array}{l}\text { Komunikasi dengan } \\
\text { Peserta didik }\end{array}$ & $52 \%$ & $82 \%$ \\
\hline 7 & \multicolumn{3}{|c|}{ Penilaian \& evaluaspi } \\
\hline
\end{tabular}


Pada tabel di atas tampak bahwa setiap aspek kompetensi mengalami peningkatan atau perubahan perilaku guru. Aspek yang paling tinggi mengalami peningkatan adalah kompetensi pengembangan potensi peserta didik. Aspek yang lain berubah meningkat dalam katagori sangat baik. Ilustrasi peningkatan lebih jelas dapat dibandingkan dengan grafik 1 berkut memberikan gambaran lebih jelas.

Grafik 1. Rekap penilaian dua siklus untuk Kompetensi pedagogik Guru di SDN Kepanjen 2

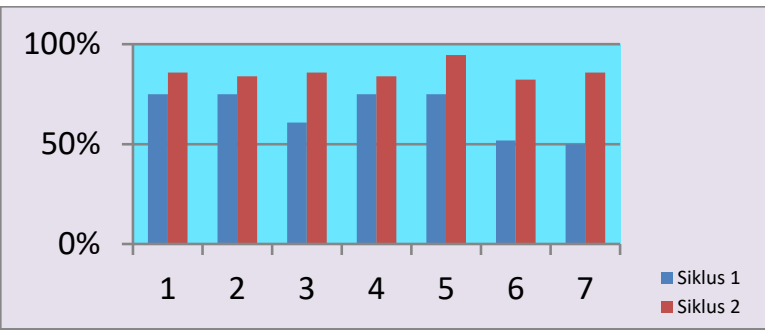

\begin{abstract}
Perubahan perilaku guru dalam berdasar-kan hasil penilaian setelah mendapatkan tindakan di siklus I menunjukkan perubahan yang belum mencapai target minimal yang peneliti tetapkan. Hasil yang dicapai oleh 14 guru rerata nilai kompetensi pedagogik berada di bawah prestasi baik. Tampak jelas dapat dilihat pada grafik 2 berikut

Grafik 2. Rekap penilaian pada siklus I untuk Kompetensi Pedagogik Guru di SDN Kepanjen 2
\end{abstract}

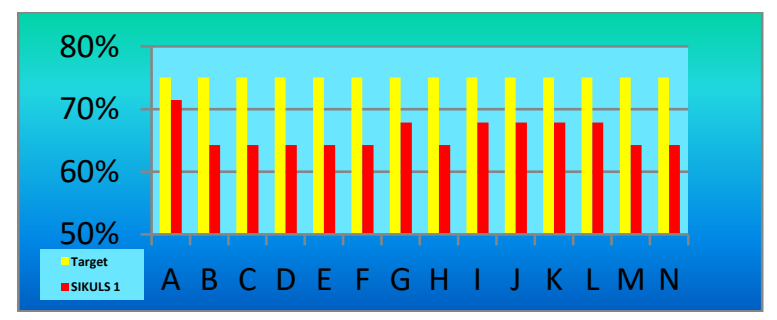

Pada siklus II perubahan perilaku guru dalam kompetensi pedagogik meningkat den dari 14 orang terdapat 13 orang yang telah berhasil meningkatkan kompetensinya dengan mencapai lebih dari target minimal yang ditetapkan peneliti. Ini membuktikan bahwa perlakukan supervisi akademik oleh peneliti memberikan dampak positif dan mampu meningkatkan kompetensi guru dengan baik. Secara jelas dapat dilihat pada grafik 3 berikut.

Grafik 3. Rekap penilaian pada siklus II untuk Kompetensi Pedagogik Guru di SDN Kepanjen 2

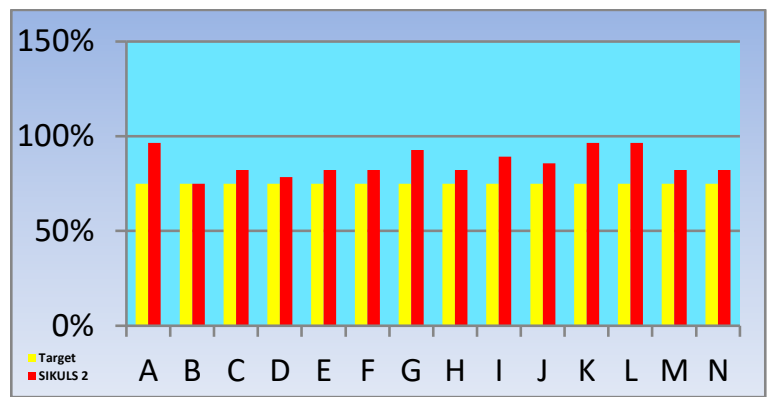

Dari keseluruhan guru rerata menunjukkan pertumbuhan peningkatan kompetensi antar 9\% - 20\%, secara jelas dapat disajikan dengan grafik 4 tentang perbedaan capaian kompetensi guru pada siklus I dan siklus II.

\section{Grafik 4. Rekap penilaian perbedaan capaian kompetensi pedagogik Guru pada siklus I dan II di SDN Kepanjen 2}

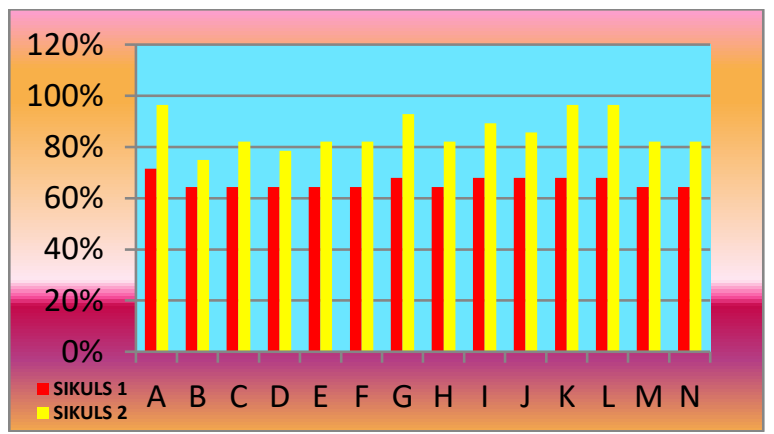

Secara umum perlakuan tindakan pada penelitian ini dimana penerapan supervisi akademik untuk meningkatkan kompetensi pedagogik yang dilakukan di SDN Kepanjen 2 telah membuktikan memberikan dampak positif dan menunjukkan adanya peningkatan kompetensi pedagogik guru.

Penerapan supervisi akademik dalam penelitian ini terbukti dapat meningkatkan kompetensi pedagogik guru. Dengan langkah-langkah yang telah dibakukan dalam teori supervisi akademik yaitu: 1) membangun hubungan yang harmonis dengan guru; 2) menganalisis kebutuhan; 3) mengembangan strategi dan media 
supervisi; 4) melakukan observasi; dan 5) mengadakan refleksi. Lima langkah tersebut merupakan langkah bagu yang diterapkan peneliti pada dua siklus yang dilakukan sebagai tahapan tindakan.

Secara umum perubahan yang terjadi pada kompetensi guru dalam aspek pedagogik telah mencapai peningkatan pada setiap siklus. Artinya tindakan supervisi akademik pada setiap siklus dapat memberikan dampak yang baik untuk membantu kemampuan guru dalam melaksanakan pengelolaan pembelajaran, seperti dilukiskan oleh grafik 5 berikut.

\section{Grafik 5. Rekap penilaian perbedaan capaian kompetensi peda-gogik Guru pada siklus I dan II di SDN Kepanjen 2}

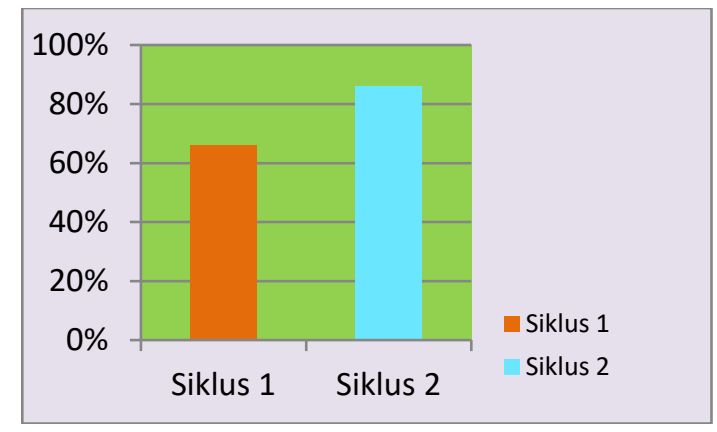

Dalam grafik tersebut dapat dibaca bahwa rerata seluruh guru (14 orang) telah mencapai peningkatan dan dari siklus I ke siklus II mencapai peningkatan yang besar.

Tindakan dalam PTS ini telah mampu memberikan kontribusi untuk meningkatkan mutu pendidikan di sekolah dengan dibuktikan bertambahnya mutu pembelajaran yang diberikan guru kepada peserta didik. Peningkatkan kompetensi pedagogik guru menurut (Ismail, 2010) yang meliputi; menguasai karakteristik peserta didik, menguasai teori belajar dan prinsipprinsip pembelajaran yang mendidik, pengembangan kurikulum, kegiatan pembelajaran yang mendidik, pengembangan potensi peserta didik, komunikasi dengan peserta didik, penilaian dan evaluasi, akan memberikan arti yang luar biasa dalam proses membangun pengalaman belajar peserta didik. Oleh karena tujuan supervisi tidak hanya memberikan peningkatan kompetensi guru, akan tetapi memiliki multi tujuan.
Supervisi akademik yang baik adalah supervisi akademik yang mampu berfungsi mencapai multitujuan tersebut di atas. Tidak ada keberhasilan bagi supervisi akademik jika hanya memperhatikan salah satu tujuan tertentu dengan mengesampingkan tujuan lainnya (Sudin, 2008). Hanya dengan merefleksi ketiga tujuan supervisi akademik akan berfungsi mengubah perilaku mengajar guru. Pada gilirannya nanti perubahan perilaku guru ke arah yang lebih berkualitas akan menimbulkan perilaku belajar peserta didik lebih baik.

\section{KESIMPULAN}

Proses penerapan supervisi akademik dapat berjalan dengan baik sesuai dengan langkah-langkah yang menjadi karakteristik supervisi akademik dalam meningkatkan kompetensi pedagogik guru. Langkahlangkah yang dimaksud adalah: 1) menciptakan hubungan yang harmonis, 2) analisis kebutuhan, 3) mengembangkan strategi dan media, 4) menilai, dan 5) revisi.

Hasil analisa data yang ada diperoleh paparan yang membuktikan bahwa penerapan supervisi akademik dapat meningkatkan kompetensi pedagogik guru di SDN Kepanjen 2 Jombang. Keberhasilan hasil penelitian terhadap masing-masing aspek kompetensi peda-gogik secara rinci pada akhir siklus II diperoleh nilai sebagai berikut: 1) Pencapaian Kompetensi menguasai karakteristik peserta didik $86 \%$, 2) Pencapaian Kompetensi menguasai teori belajar dan prinsip pembelajaran yang mendidik 84\%, 3) Pencapaian Kompetensi pengembang-an kurikulum 86\%, 4) Pencapaian Kompetensi kegiatan pembelajaran yang mendidik $84 \%$, 5) Pencapaian Kompetensi pengembang-an potensi peserta didik 95\%, 6) Pencapaian Kompetensi komunikasi dengan Peserta didik 82\%, 7) Pencapaian Kompetensi penilaian dan evaluasi $86 \%$

Dari tujuh kompetensi tersebut dapat diperoleh nilai rata-rata $86 \%$. Jadi dapat disimpulkan bahwa penerapan supervisi akademik dapat meningkatkan kompetensi pedagogik guru di SDN Kepanjen 2 Kecamatan Jombang Kabupaten Jombang pada tahun 2016 


\section{SARAN}

Kepala sekolah dituntut untuk mampu memberdayakan guru utamanya dalam pembelajaran agar dapat meningkatkan produktivitas dalam membentuk potensi peserta didik. Oleh karena itu Kepala sekolah harus mampu melakukan tindakan supervisi akademik sebagai salah satu bentuk layanan memberikan bantuan kepada guru agar dalam melaksanakan pembelajarannya berkualitas. Hasil penelitian ini merupakan keberhasilan Penelitian Tindakan di SDN kepanjen 2 Jombang. Oleh karena itu akan lebih sempurna konsep keberhasilan ini perlu diuji oleh peneliti lain yang berkenan untuk diterapkan di tempat lain. Sehingga apa yang menjadi keberhasilan dari penelitian ini dapat menjadi referensi untuk penelitian lebih lanjut.

\section{DAFTAR RUJUKAN}

Arikunto, S. (2005). Manajemen Penelitian. Jakarta: Rineka Cipta.

Astuti, S. (2016). Penerapan Supervisi Akademik untuk Meningkatkan Kompetensi Guru dalam Menyusun Administrasi Penilaian di SD Laboratorium UKSW. Scholaria : Jurnal
Pendidikan Dan Kebudayaan, 6(1), 117. https://doi.org/10.24246/j.scholaria.201 6.v6.i1.p117-126

Dharma, S. (2007). Supervisi Pendidikan dan Peningkatan Profesionalisme Guru. Jakarta: Dirjen PMPTK.

Ismail, M. . (2010). Kinerja dan Kompetensi Guru dalam Pembelajaran. Lentera Pendidikan, 13(1), 44-63.

Nurgiyantoro, B. (2004). Penilaian Pembelajaran Sastra Berbasis Kompetensi. Diksi, 1J(1), 91-116.

Pidarta, M. (2011). Supervisi Pendidikan Kontekstual. Jakarta: Rineka Cipta.

Riyanto, Y. (2007). Metodologi Penelitian Kualitatif dan Kuantitatif. Surabaya: Unesa Press.

Sudin, A. (2008). Implementasi Supervisi Akademik Terhadap Proses Pembelajaran di Sekolah Dasar Se Kabupaten Sumedang. Pendidikan Dasar, 9, 28-31.

Wardani, I. (2013). Pemantapan Kemampuan Profesional (PKP). Jakarta: Universitas Terbuka.

Widoyoko, E. . (2012). Teknik Penyusunan Instrumen Penelitian. Yogyakarta: Pustaka Pelajar. 